NBER WORKING PAPER SERIES

\title{
WHY FIRMS OFFER PAID PARENTAL LEAVE: AN EXPLORATORY STUDY
}

\author{
Claudia Goldin \\ Sari Pekkala Kerr \\ Claudia Olivetti \\ Working Paper 26617 \\ http://www.nber.org/papers/w26617 \\ NATIONAL BUREAU OF ECONOMIC RESEARCH \\ 1050 Massachusetts Avenue \\ Cambridge, MA 02138 \\ January 2020
}

We are extremely grateful to Namrata Narain, the primary RA on the project, to Jennifer Walsh who followed her, and to Valeria Ferraro who ably assisted in collecting data on firm-level benefits. Kristen Monaco of the BLS kindly helped us obtain the cross-tabulations of the Economic Benefits Survey (EBS). We thank Dev Patel and participants at the HKS-WAPPP seminar for providing helpful comments. The Russell Sage Foundation (Grant \#85-18-05) and the NSF (Grant \#1823635) are to be gratefully acknowledged for providing the research funding. We presented an earlier version of this paper at the AEI/Brookings "Paid Family and Medical Leave Author's Conference," November 19, 2019. We thank the participants and especially our discussant, Ann Bartel, for helpful comments. The views expressed herein are those of the authors and do not necessarily reflect the views of the National Bureau of Economic Research.

NBER working papers are circulated for discussion and comment purposes. They have not been peer-reviewed or been subject to the review by the NBER Board of Directors that accompanies official NBER publications.

(C) 2020 by Claudia Goldin, Sari Pekkala Kerr, and Claudia Olivetti. All rights reserved. Short sections of text, not to exceed two paragraphs, may be quoted without explicit permission provided that full credit, including $(\odot$ notice, is given to the source. 
Why Firms Offer Paid Parental Leave: An Exploratory Study

Claudia Goldin, Sari Pekkala Kerr, and Claudia Olivetti

NBER Working Paper No. 26617

January 2020

JEL No. J13,J2,J32

\begin{abstract}
$\underline{\text { ABSTRACT }}$
Why do competitive firms in the US provide paid parental leave (PPL)? Which firms do and to what extent? We use several firm- and individual-level data sets to answer these questions. These include the BLS-Employee Benefit Survey (EBS) for 2010 to 2018 and an extensive firm-level data collection that we compiled. Our work is undergirded by a two-period model with competitive firms whose workers vary by their optimal firm-specific training and the probability that each will remain on the job after PPL is taken. We find that firm-provided PPL has greatly increased in the last two decades and generally covers new fathers. The levels of provision differ greatly by the industry, firm size, and the degree of firm-specific training. But even the top-ofthe-line firm in the US provides fewer fully paid parental weeks than does the median OECD nation.

Claudia Goldin

Department of Economics

229 Littauer

Harvard University

Cambridge MA 02138

and NBER

cgoldin@harvard.edu

Sari Pekkala Kerr

Wellesley College

106 Central Street

Wellesley, MA 02481

skerr3@wellesley.edu

Claudia Olivetti

Department of Economics

Dartmouth College

6106 Rockefeller Hall

Hanover, NH 03755

and NBER

claudia.olivetti@dartmouth.edu
\end{abstract}


Even though the US is in last place in the paid and job-protected family-leave Olympics, many states have stepped up to the plate offering paid family and medical leave. Until a few years ago, the only states that offered paid leave (or passed paid leave legislation) were those with Temporary Disability Insurance (TDI) programs (CA, NJ, NY, RI). ${ }^{1}$ But, more recently, other states have begun to formulate paid family leave legislation following the leads of WA and MA. MA recently passed a paid-leave law using its Unemployment Insurance (UI) system to administer the additional tax contributions.

At the time of this writing, two more have joined the list of states that have passed paid family leave legislation, and more than a dozen states across the political spectrum are expected to introduce legislation soon including liberal states, such as $\mathrm{CO}, \mathrm{MN}$, and $\mathrm{ME}$, and more conservative ones, such as IN, NE, and OK. Paid family leave could soon become law in enough states to render a federal act unnecessary, similar to what happened to workers' compensation from 1910 to 1921 when all but five states passed a law. ${ }^{2}$

But even if all states passed a paid family leave law at the level of the most generous state today, the US would still be in last place in the world, most likely tied with Mexico at 12 weeks of (partially) paid leave. ${ }^{3}$

At the same time that states have been filling in for the federal government, firms have been filling in for both. Firms in states without paid family leave are providing their own form of insurance, and firms in states with leave often "top off" the amount of earnings replacement and extend the number of paid weeks.

We should be clear at the outset that our paper mainly concerns Paid Parental Leave (PPL) - paid employee leave to care for newborns (and adopted children). PPL can be gender neutral. But, in most cases, women are offered more PPL than are fathers, and birth mothers often must take the firm's Short-Term Disability before they are eligible for PPL. Even though firms often require employees to use personal days off (e.g., vacation, sickness) before they access paid parental leave days, our compilations of PPL try to

\footnotetext{
${ }^{1}$ One reason that US states with temporary disability programs can have paid family leave is that it provided the fiscal apparatus needed to fund the social insurance program. Another is that pregnancy is treated as a disability. DC also has a paid family leave policy.

2 On the history of workers' compensation see Fishback and Kantor's aptly titled book A Prelude to the Welfare State: The Origins of Workers' Compensation (2000).

${ }^{3}$ California, with six weeks of disability leave for mothers and another six to eight weeks of paid family leave, is the most generous state today. The replacement rate is $70 \%$ and the maximum weekly payment is $\$ 1,216$. For comparison, in 2018 the median duration of paid maternity leave across OECD countries was 16 weeks, with a median average payment rate of approximately $80 \%$ of average national full-time earnings. See:

https://www.oecd.org/els/soc/PF2 1 Parental leave systems.pdf.
} 
measure the PPL benefit separately from other leaves.

PPL is generally distinct from benefits that grant paid leave to care for sick children and other family members, also known as Paid Family Leave (PFL). It is also distinct from medical leave for oneself, often termed Short-Term Disability. Many firms lump vacation, personal, and sick days together and give them as an aggregate "paid time off" benefit. 4 Because monitoring is costly, except in the case of births and adoptions, firms that offer PPL, often also provide a lump of paid time off days (PTO) for all other reasons. One exception is Short-term Disability, which is occasionally a separate benefit that is free or offered at subsidized rates. We provide summaries on the levels of PTO from our firm data.

Our reasons for concentrating on PPL as a subset of paid family and medical leave are several. Even though paid family and medical leave can encompass a host of circumstances, including leave by the worker to care for relatives and for the worker's own short-term disability, a substantial fraction of such leaves are taken by new parents, both mothers and fathers. In California, for example, about $70 \%$ of paid family leave claims by female workers, 20 to 39 years old, are for births and adoptions. ${ }^{5}$

Another reason to concentrate on the maternity and infant bonding aspects of the family and medical leave benefit is that firms tout those benefits when recruiting new employees, possibly because applicants are younger than existing workers. Also, most of the economics literature on the impact of current state plans emphasizes their impact on birth mothers' employment and earnings post leave. ${ }^{6}$ Finally, a main drawing card of the state plan advocates is that PPL is both woman and child centered.

The focus of our paper on PPL does not imply that other forms of caring and medical

\footnotetext{
${ }^{4}$ Most of these terms are defined in the EBS glossary: https://www.bls.gov/ncs/ebs/nationalcompensation-survey-glossary-of-employee-benefit-terms.htm\#paid leave

5 Bana, Bedard, Rossin-Slater, and Stearns (2018), table 3, indicates that, among women 20 to 39 years old, there were 0.778 disability claims and 0.345 "bonding" claims. Assuming that each "bonding" claim is also a disability (maternity) claim and that 0.235 (the value for men) claims have nothing to do with a birth, then 0.198 claims were for births without a bonding claim. This implies that $70 \%(0.543 / 0.778)$ of all claims for women 20 to 39 years involved a birth (or adoption). The 0.235 figure assumes that disability claims that are not for births are the same for males and females. That is probably an overstatement for women and thus the fraction of all claims for women that involve a birth would be even higher. We ignore the small fraction with caring leaves. ${ }^{6}$ Baum and Ruhm (2016), using the NLSY97, find that female employment increased with CA-PFL seven to 12 months after a birth. Rossin-Slater et al. (2013) show that CA-PFL increased leaves for mothers by about three weeks and that PFL had a positive impact on their later employment. Bycker (2016) finds that the increase in worker attachment after leave comes mainly from the lower-educated group of women. Others have noted that employers may be less likely to promote women (and possibly men) who take leave and that maternity leave takers may have had slower wage growth after passage of FMLA (Manchester, Leslie, and Park 2008; Thomas 2019).
} 
leave are unimportant to firms and their employees. In fact, our discussion of the BLS data concerns PFL, rather than PPL, since the data collected are for paid family leave even though the majority taken is probably in the form of PPL.

We begin with an overview of national data on paid leave at the individual level as provided by the National Survey of Family Growth (NSFG). We then move to firm-level data, first those collected as part of the Employee Benefit Survey (EBS) by the BLS. Finally, we present and analyze our collection of firm-level data for a vast array of firms and compare the aggregate findings from the EBS to ours at the firm-level.

The firm-level data motivate our central questions: Why do firms that compete in product (and labor) markets provide paid family or paid parental leave and which firms provide this benefit and at what levels? We frame our answers to these questions in a twoperiod model with competitive firms, and workers who are, ex ante, identical except for the expected value they place on returning to work after a birth. That determines their optimal firm-specific training and the degree to which each will remain on the job if PPL is taken. The model has a number of implications regarding which firms provide PPL and how much is provided.

We then move to an analysis of our firm level data using the insights from our model. We provide data on the levels of PPL by industry, size of firm, percent female, age distribution of employees, and the home-office state. We provide extensions to our data for three professional service industries for which we know the identity of all firms by number of employees. We also explore the provision of fully-paid personal days (PTO). We end with a summary of our findings.

A. Paid Parental and Family Leave: Evidence from Firms

1. The Data: Firm-Level and Aggregate

To understand the amount of paid family or parental leave offered by private-sector firms and used by employees, we use three sources. The first is the National Survey of Family Growth (NSFG), which asks respondents about the leave they took after a birth. We tabulate the leave they took for which they received remuneration. One potential drawback is that the NSFG data do not specifically concern leave provided by private-sector firms, about which we are concerned here. In addition, the benefit used may include accumulated sick and vacation days.

The second source is the Employee Benefits Survey (EBS) collected by the BLS. The EBS is the most comprehensive source to measure firm-level benefits in the US, including 
paid family leave (PFL). The data are available in a consistent form from 2010 to 2018 . But because they are confidential, they can be accessed only as tabular materials by industry, occupation, and separately by characteristics of firms and workers, such as number of employees and wage percentiles.

The final source, and the one that is our main contribution, is our extensive collection of firm-level PPL information. The main data used in the paper come from Great Place to Work (GPTW) and are for 2017/18.7 We also use a host of other sources including compilations by various aggregators and the Working Mother magazine

We have compiled extensive information on 1,135 firms, for which we have paid parental leave (PPL) benefits information on 960 firms. The availability of various correlates, including employment, the state of the headquarters, and the composition of the firm's workforce, reduces our sample to around 500 to 600 for the regression analyses.

The policies listed by firms are often complex. Firms do not always clearly state whether their short-term (or temporary) disability program is included in the number of PPL weeks they claim to offer and whether workers who take PPL are first required to exhaust their vacation, and sick days. Even more difficult is figuring whether all workers at the firm are covered. When the firm provides data for full-time and part-time workers separately, we use only the data for full-time workers.

The coverage that we list was given as the full replacement rate. Some firms offer full replacement for some period and then partial replacement beyond that. In most cases we use only instances of full replacement and exclude partial replacement. ${ }^{8}$ We emphasize that we have tried to use data only for the firms that provide nearly universal fully-paid parental leave.

There is also the question of employee coverage. Many of the firms we list are professional service firms. We often do not have direct information on whether firm policies cover staff positions to the same degree they cover professionals. But auxiliary information indicates that most cover both. Recent news articles reveal that large law firms generally have leave equality between attorneys and administrative staff. Many have recently changed from a previous two-tiered system where administrative staff had been eligible for a shorter paid leave than the attorneys. ${ }^{9} \mathrm{~A} 2017$ survey of 18 law firms by the

\footnotetext{
7 The benefits data we obtained from Great Place to Work were listed for 2017. Our web scouring and phone calls may include some data for 2018. See Appendix: Firm-Level Data for details. 8 Our data set has just a small number of firms with partial replacement or a mixture of both. ${ }^{9}$ Based on a 2017 survey of 44 large law firms, the issue is discussed further in: https://news.bloomberglaw.com/daily-labor-report/big-law-firms-have-sharp-divide-on-parental$\underline{\text { leave-policies }}$
} 
Diversity and Flexibility Alliance shows that just 22 percent of the firms had no paid parental leave for the staff. 10

Because much of the firm-level information we have collected comes from aggregator websites that applaud the family-friendly policies of our sample firms, we will be missing firms that provide no, or few, benefits. Firms tout their benefit packages, such as PPL, but do not advertise a program's absence or its restrictions in covering only those in salaried positions. To address the problem of the "missing zeros," we have supplemented our sample. We have done a deeper dive into three well-defined sectors-Accounting, Law, and Finance \& Insurance-for which the top hundred or so firms by number of employees are clearly known. See Appendix: Firm-Level Data.

We also present evidence on changes in PPL coverage from around 2000 to 2017 for various industries to demonstrate how benefits have increased in a follow-the-leader manner. Finally, we analyze information on a broader form of "caring leave" - fully paid personal days or personal time off (PTO).

2. National Survey of Family Growth and CPS Data

The National Survey of Family Growth (NSFG) provides the best individual-level estimates of the fraction of women who received paid parental leave. The survey spans 2001 to 2010 . Female respondents, 15 to 45 years old, were asked whether they were at work at the time of their most recent pregnancy and whether they were able to take any leave after that birth. ${ }^{11}$

Of those who could take any kind of leave, the number of paid weeks was requested. Those who were unable to take leave include those who left employment at the time of the birth with no intention of returning and those working in firms or business that were not subject to FMLA (e.g., small businesses).

We divide the sample into two groups by education. Among the college graduate group, about $80 \%$ of those who were at work while pregnant took some leave (paid or unpaid). ${ }^{12}$ In addition, $64 \%$ of those who were at work while pregnant received paid leave of some duration. Among the group who received paid leave, $45 \%$ received six or more

\footnotetext{
${ }^{10}$ See https://dfalliance.com/action-step-inclusive-flexible-work-policies-include-staff/

11 We have tabulated the data by the year of the child's birth, but the sample sizes are too small to allow consideration of year effects. In addition, there are few consistent differences by birth year. 12 Those who did not take leave probably left the workforce, although some may have not been covered by FMLA and left employment without any job protection.
} 
weeks; $20 \%$ received ten or more. The mean number of weeks for those receiving some paid leave was about eight.

The situation for mothers with an education below college graduate is rather different. In the lower-educated group, $64 \%$ of those who worked while pregnant took some leave (paid and unpaid). Just 36\% of women who were at work while pregnant received some paid leave. Of those, $30 \%$ received six or more weeks and $10 \%$ received ten or more weeks. Even though a much smaller fraction of the lower-educated group received any paid leave, the mean number of weeks for those receiving some paid leave-at 7.6 weeks - was almost the same as for the college graduate group.

The NSFG is useful for placing the firm-level data in a larger context.13 The comparison that we will make is of the mean number of leave weeks conditional on having paid leave. The more-educated group of mothers receive far more leave than do the lesseducated group. But all women with paid leave receive about eight weeks. The firms in our data provide more leave, but that is to be expected since they were chosen because of their more generous leave policies and because they provide fully-paid leave. The surprising finding is that they do not provide that much more paid leave than the national average of what new mothers take.

\section{BLS Employee Benefits Survey (EBS) Data}

The EBS is the only source of benefits statistics of private-sector firms at the national level. Because of the confidentiality of the firm-level microdata, BLS researchers kindly provided us with cross tabulations of industries by firm size bins and also occupations by wage bins (when the number of observations is sufficiently large by cell). We use the EBS industry data since they are most comparable with our firm data.

An important point about the EBS data is that they give the fraction of employees with any level of a particular benefit, such as paid vacation, paid sickness and family leave, and unpaid family leave. We give, in Figure 1, annual information from 2010 to 2018 for the fraction of firms that offered PFL (of any length) in six industries (the BLS uses NAICS codes) by firm size. ${ }^{14}$ Note that EBS data are at the firm level and implicitly assume that all workers are covered by a benefit if the firm offers that benefit. We cross classify size of firm

\footnotetext{
13 The NSFG does not distinguish between women who had been employed in the private and public sectors, whereas our evidence here only concerns the private sector. For evidence on paid and unpaid leave taken by women working in the private sector, see Kerr (2016), which uses the NLSY79 and explores the impact of FMLA.

14 The BLS uses the North American Industry Classification System (NAICS). We use the higher level of aggregation except for the Professional \& Technical and Health Care \& Social Assistance industries.
} 
in two buckets ( $<100$ workers and $\geq 100$ workers) as that is the only firm size variable that has no missing cells for the six industries. ${ }^{15}$

Access to PFL across all industries increased from $11 \%$ to $17 \%$ of all workers between 2010 and 2018. ${ }^{16}$ A main finding from the EBS industry data is that the trend in PFL provision from 2010 to 2018 was distinctly upward, particularly in industries having significant levels in the base year. In the Information and Professional \& Technical sectors, for example, the fraction of firms offering PFL nearly doubled from around $15 \%$ to $20 \%$ to $30 \%$ to $40 \%$ in the 18 years. But in industries like Manufacturing and Retail, where the initial levels were low, there was only a minor increase.

Also important is that there are significant differences by industry in all years, given size of the firm. In the Information, Finance \& Insurance, and Professional \& Technical industries, $45 \%$ of larger firms offered PFL to their workers in 2018. In the Manufacturing and Retail Trade sectors, however, barely $10 \%$ of the larger firms offered PFL, and $20 \%$ of the larger firms in the Health sector offered PFL.

Large firms ( $\geq 100$ workers) in all industries offer more paid leave than small firms ( $<100$ workers). In the Professional \& Technical sector, $19 \%$ of the small firms offered PFL but $40 \%$ of the large firms did in 2017. In Finance \& Insurance, $37 \%$ of the small firms offered PFL but $43 \%$ of the large ones did, and in Health Care and Social Assistance it was $13 \%$ versus 22\%. The low levels of provision in Manufacturing conceal the fact that there are large differences by size. Retail shows little difference by size, although the enormous increase for larger firms in 2018 was almost certainly caused by Walmart's PFL change that year. ${ }^{17}$

4. Comparing the EBS and Firm-level Data

Our firm-level data give the number of days of paid leave (separately for birth mothers, fathers and, often, adoptive parents) conditional on having some PPL. ${ }^{18}$ The

15 Missing cells occur when the number of firms in a cell is too small for the BLS to report.

16 See https://data.bls.gov/timeseries/NBU18700000000000033349.

17 In March 2018, Walmart began to offer ten weeks of fully paid maternity leave to all full-time hourly and salaried employees. Walmart also offers six weeks of paid parental leave, giving 16 weeks total for birth mothers and six weeks for fathers. See:

https://smartguide.walmartone.com/SmartPages/Media/Default/LeadershipGuide/MaternityParental-FAQ-2018.pdf

18 There are some firms that list "primary caregiver" (referred to in some literature as "primary custodial parent") as the individual who can collect the PPL. A class-action sex-discrimination case against JPMorgan Chase brought by male plaintiff Derek Rotondo was recently settled for $\$ 5$ million and may provide an important precedent giving men the ability to be considered as primary custodial parents when they request the full PPL. Case law in the area is still in flux, however. See 
construction of the EBS data make the implicit (and not always believable) assumption that a firm policy for any worker applies to all workers equally.

As shown in Figure 2, the Finance \& Insurance, Information, and Professional \& Technical industries all have high fractions of PFL in the EBS sample and, generally, the greatest number of days of PPL leave offered in the firm-level data. Because the firm-level dataset has disproportionately large firms, the EBS data for the larger firms are more relevant. ${ }^{19}$

As seen in the second panel of Table 1, the mean number of PPL days for mothers in the analysis sample of firms is 46 and is 54 when weighted by the firm's employees. In the expanded sample of firms the mean number of PPL days is 55, and is 69 when weighted by the firm's employees. Around ten to twelve weeks seems to be a norm for firms that offer leave. ${ }^{20}$ Some sectors have higher PPL than suggested by the EBS data. For example, our Retail sample, while small, indicates that leaders in the industry are providing PPL for all employees. $^{21}$

Earlier, we produced estimates from the NSFG on weeks of paid leave taken by women by education group. For the college graduate group about eight weeks were taken and for the non-college graduate group a slightly smaller number of weeks were. As we pointed out, even though leave length conditional on some paid leave are about the same by education, the fraction of non-college graduate women who can take paid leave is just half that for college graduate women.

The weighted means in Table 1, part A are higher than those in the NSFG, and that is to be expected given that our firm-level data comes from those that provide paid leave and boast about it. But the differences are not enormously large-around 54 days for our firms

https://www.cbsnews.com/news/pmorgan-chase-to-pay-5-million-to-male-employees-who-saythey-were-unfairly-denied-parental-leave/

19 The largest size division we have for the EBS is 500 workers and the median size for the firmlevel sample is 1,000 workers. In addition, the EBS cross-classified data for the large firms is not available for all industries and all years.

20 Table 1 indicates that firms in Finance \& Insurance have only slightly higher (by about two weeks, employment weighted) PPL, than those in Manufacturing, which would appear different from the EBS data. The manufacturing firms in the firm-level data are the larger ones (e.g., GM, GE, Ford, PepsiCo, Boeing, Johnson \& Johnson, Eli Lilly, Merck, Abbott). The relationship is attenuated when the firm's employment is held constant. But the difference between the firm and the EBS data shows the importance of finding the firms that provide no PPL.

${ }^{21}$ It is likely that benefits are provided for those who have some tenure with the firm. 
versus around 40 days for new mothers in the NSFG. ${ }^{22}$

Not surprisingly, firms offer fewer days of PPL to fathers than to mothers. The mean firm, weighted across all industries, in the analysis sample offers 24 fewer days to fathers, or about five fewer weeks. ${ }^{23}$ The difference is consistent with the notion that birth fathers get baby-bonding time that is often similar to that offered to birth mothers, but mothers also get five to six short-term disability weeks.

The firms in our sample have worker benefits that are more generous than those of the average firm. Firms in our analysis sample have been singled out as being a "good place to work." Although some are large, there are also many small firms in our sample. In the analysis sample (for mothers) of 384 firms, the mean number of employees is 5,444 but the median is 440 and $25 \%$ have fewer than 110 employees. ${ }^{24}$

It should be noted that all but small firms in the US are mandated to have a policy with regard to protected, unpaid family leave since firms with more than 50 employees (within a 75-mile radius of the company's worksite) are covered by the federal Family and Medical Leave Act (FMLA). In the EBS, $88 \%$ of all firms have such a policy and $95 \%$ of those with more than 500 employees do. 25

5. Changes in PPL over Time

The EBS data show substantial increases in PFL over time for industries that had a modicum of coverage in 2010, the base year. To explore changes over time by firm, we have also collected information on leave policies from Working Mother magazine's best companies from around 2003 to 2017, similar to the years given in the EBS. Only the largest firms are included by Working Mother in each of the following sectors: Professional Services, Financial Services (consumer finance, insurance, corporate banking), Biotech, Manufacturing, Healthcare, and Technology.

PPL increased in each of these sectors during the 15 or so years. The largest gains were in Professional Services and Financial Services, but all had gains. We have the most complete information by firm in Professional Services. Those data reveal a follow-the-

\footnotetext{
22 We use the analysis sample in part A that does not include the added professional service firms. The data weighted by the number of employees average 54 days; the unweighted mean is 42 days. ${ }^{23}$ Calculated using only firms with positive PPL and averaged by firm across all industries, including those "not classified."

${ }^{24}$ In the expanded sample (for mothers), which by design has larger firms, the mean number of employees is 21,785 (745 firms) but the median is 1,237 and $25 \%$ have fewer than 278 employees. 25 See U.S. Department of Labor (2017) table 32, March 2017. The reason 100\% of the larger firms do not have a policy is because there are many smaller work sites, more than 75 miles apart.
} 
leader strategy where one of the companies increases benefits and then the others follow within a few years until they all bunch at about the same number.

For example, in 2003 the big accounting and consulting firms all offered between two and nine weeks PPL for mothers. PwC and Deloitte were in the lead with nine. But in 2006 BCG led with 12 and in 2015, KPMG was in the lead at 16. By 2017, Deloitte was leading the pack at 22 weeks of paid leave. Accenture, PwC, KPMG, and McKinsey were all bunched around 14 . They are probably still playing a game of leap-frog, competing for workers with similar skills in the same markets. ${ }^{26}$

B. Why Firms Provide Paid Parental Leave (PPL): A Simple Two-Period Model

Paid leave is a cost to the firm. Its value to workers depends on age, gender, and various circumstances. Why are firms in some industries more apt to offer PPL than in other industries? Why do firms provide paid leave and why have firms increased their PPL coverage in the past decade? ${ }^{27}$

We develop a two-period model to understand why competitive, profit-maximizing firms offer PPL. Simply put, a firm will offer PPL if its workers value it sufficiently and if enough of their workers are bonded to the firm so that they return after taking PPL. The model's structure is reminiscent of Lazear and Rosen (1990). ${ }^{28}$

The model has two key ingredients for workers. One is firm-specific human capital investment, $\alpha_{i}$, undertaken in period one ( $\left.\mathrm{P}_{1}\right)$ and increasing the worker's wage in the second period $\left(\mathrm{P}_{2}\right)$. The second is a stochastic value of time, $v$, after a worker has a birth, which occurs with probability $p$ between $\mathrm{P}_{1}$ and $\mathrm{P}_{2}$. The precise value of $v$ is unknown at the time of the human capital investment but its distribution is known.

Each of $N$ firms (i) has a unique minimum amount of firm-specific human capital investment $\left(\alpha_{i}\right)$ required by each of their employees to be a productive worker in the firm. All employees of firm $i$ will invest the same $\alpha_{i}$ in $\mathrm{P}_{1}$. In addition to paying wages, firms can offer PPL of some duration covering all employees who have a birth.

\footnotetext{
${ }^{26}$ McKinsey is not listed in GPTW, probably because it does not need to advertise the generosity of its benefits. The GPTW firms omit several other well-known employers.

27 The question is related to the literature on the provision of employee benefits versus higher wages (e.g., Eriksson and Kristensen 2014; Oyer 2008). Oyer points out that including nonpecuniary benefit in the compensation package acts as a sorting mechanism to attract and retain key employees.

28 The full-blown version is provided in Appendix: Two-Period Model of Paid Parental Leave (PPL).
} 
Firms have two types of workers, Male (M) and Female (F), who are potentially perfect substitutes in production. Each worker has a cost of investment effort $(\varepsilon)$, identically distributed, $f(\varepsilon)$, and known to all. All workers face a probability $p$ of having a child after $\mathrm{P}_{1}$. In the event of a birth, they will value time at home at $v$, distributed $g_{m}(v)<$ $g_{f}(v)$ for all $v$, known to all. But workers do not know the precise value of $v$ until experiencing the birth and taking leave in $\mathrm{P}_{2}$. The cost of effort function, $f(\varepsilon)$, and the value of time, $g_{m, f}(v)$, distributions are orthogonal.

The key source of gender difference in our model is that women have a higher value of nonmarket time in expectation. Gender matters because $g_{m}<g_{f}$. Women will do less investing because they know that, on average, they are more likely to value home time more than wage in $\mathrm{P}_{2}$ and exit the firm after leave. Note that some men will also exit at the end of their leave.

At the start of $\mathrm{P}_{1}$, men and women sort into firms by their investment effort cost and by gender. Workers choose whether and how much to invest in firm-specific human capital leading to proportionally higher earnings in $\mathrm{P}_{2}$. To invest, workers have to forgo earnings during the investment period $(\alpha)$. Because workers have children with probability $p$, they will not recoup their investment with certainty. Women know that they stand a higher probability of exiting the firm after taking PPL and will, therefore, invest less.

The demand for PPL arises because workers all stand a chance of having a child. In the model, all workers with a birth (which occurs with probability $p$ ) take some duration of leave from work and then determine how much they value remaining at home beyond their paid leave. They compare their wage to their value of $v$ to determine whether they will return to the firm.

On the supply side, firms will provide PPL if a sufficient number of their workers returns to the firm after taking PPL. The reason is because the PPL benefit is financed by lower earnings among those working. Therefore, PPL will be offered if workers engage in a enough firm-specific human capital investment giving them a high-enough $\mathrm{P}_{2}$ wage.

Which firms will offer PPL with respect to worker investment and the fraction female? At one extreme, we assume that firms with workers having zero investment $(\alpha=0)$ will not offer PPL since their workers are less likely to return to work at the end of the unpaid leave and that is especially true of their female workers. If workers do come back to work, they will not necessarily return to the same firm because they will receive the same wage wherever they work. At the other extreme, firms with workers having the maximum investment ( $\alpha=1$ ) will offer PPL. The higher the level of investment, the lower the fraction female. Therefore, there is a tension between the fraction female and the level of PPL and 
the relationship can be monotonic or nonmonotonic depending on the parameters.

If there is no investment, firms will not offer PPL. But at some higher level of investment, PPL will be positive. Greater investment leads to greater bonding of workers to the firm. But a greater fraction female leads to a greater willingness to pay for the benefit.

Note that the mechanism we describe does not involve compensating differentials. In addition, there is no adverse selection. Men and women in the same firm are offered the same contracts: they receive the same wage and they are offered the same parental leave. Men are as likely to have a child as are women, although women have a higher value of nonmarket time (in expectation). In the real world, workers will probably have a good sense if and when they would like to take advantage of a PPL benefit. That possibility heightens the notion that employees with more specific human capital and those at higher pay grades will be less apt to exit the firm after taking paid leave. It is also a reason why firms with a low fraction of female employees have more generous PPL offerings. ${ }^{29}$

D. Analyzing Firm-level Parental Leave Policies

\section{Implications of the Model}

The central question we have posed is why firms offer paid parental leave. Such leaves are disproportionately taken by younger employees and by women, yet all employees in the firm pay for them. ${ }^{30}$ The model we developed suggests the characteristics of firm that would be more likely to provide fully-paid parental leave as an equilibrium condition.

A main prediction of the model is that paid leave will be provided by firms if their workers are effectively "bonded" to the firm because they have invested a sufficient amount in firm-specific training in the first period. The firms, in the model, are the higherwage firms since their workers have more training. Lower-wage firms, with lower levels of firm-specific investment, would generally not be able to offer PPL because workers would have less incentive to return to the firm, and even to work more generally, after taking a parental leave. In addition, the lower the wage, the less able and willing the workers would be to fund the benefit.

\footnotetext{
${ }^{29}$ See Manchester, Leslie, and Park (2008).

30 This point can be made for all benefits where there is heterogeneity in use and even in ex ante probabilities of use, including health care. But PPL is more clearly gender and age specific in its take-up.
} 
We also noted a factor going in the opposite direction. Firms with a greater fraction of female employees will have a larger group of workers who value PPL even if the firmspecific investment was low. Although firms with a low fraction of female employees will have lower costs of providing paid leave, firms with a high fraction of females have a larger group willing to pay for the leave. Similarly, firms with a larger fraction of workers in their child-bearing years should have the greatest willingness to pay.

Thus, the relationship between PPL and fraction female is an empirical question. They may be negatively related or the relationship may take the form of a quadratic. Note, however, that firms with no firm-specific training, and thus the highest fraction female, will likely not provide PPL.

An additional implication of the model is that, because of the insurance nature of the benefit, larger firms should offer more PPL. ${ }^{31}$ In addition, firms that compete in the labor market (in terms of the model, we mean firms that are close in terms of their minimum human capital investment requirement), will evolve a "follow the leader" strategy in providing the benefit. Although we cannot explore this prediction using the GPTW data, the firm level evidence from Working Mother magazine suggests that firms that hire particular professionals compete for labor in this manner. It is possible that they are learning about what benefits are valued by their workers, both male and female.

We mentioned before that the PPL benefit in our sample is generally for full-time salaried workers. Most firms in our sample also have a group of also salaried staff who are covered by the same PPL benefit as are the salaried professionals. But are the admins also bonded to the firm through investments in specific human capital, as the model would predict? Some of the admins could have specific human capital related to that of the professionals. But it is also possible that they receive the same benefit because of horizontal equity concerns that the professionals essentially pay for.

2. Analysis of the Firm-Level Data on PPL

\section{a. Firms with PPL}

To understand why firms provide PPL, we examine the correlates of fully paid leave days offered to new parents. We regress the number of days of leave (for mothers and fathers, separately) on the fraction female (and its square), the (log of) number of employees, indicators of the workforce's age, and dummies for states with currently active

31 The prediction is in line with the empirical literature showing that larger firms generally pay higher wages and provide more employee benefits (e.g., Brown and Medoff 1989; Dale-Olsen 2006; Davis and Haltiwanger 1996). 
policies and those with active policies in the near future. We also include industry fixed effects, when relevant.

We use the GPTW sample and thus are exploring the correlates of days of fully paid family leave given that firms are providing some PPL. We also take as given that some states had a paid family and medical leave policy in operation (or were anticipated to pass one in the near future). We later explore three industries for which we know the full list of firms and can with some accuracy identify those with no PPL.

The analysis sample firms in Table 2 (cols. 1,2) span almost the entire range of percent female, from $6 \%$ to $100 \%$ with a mean and a median of $46 \% .{ }^{32}$ As can be seen in the regression results in Table 2 (cols. 1), the fraction female is nonlinear in its impact. Days of paid family leave decrease from around 60 for the highest percentage female to 46 around the mean and then increase to around 60 again, for the lowest fraction female. ${ }^{33}$

Larger firms offer their workers more leave. Because of the insurance aspect of paid leave benefits, larger firms should be more willing to provide social insurance programs, all else equal. ${ }^{34}$ The size distribution of our analysis sample firms has a long right tail with a median of 440 but a mean 5,444. Limiting to firms with fewer than 50,000 employees yields a median of 417 and a mean of 3,241. Increasing firm size by 100 employees would, according to the estimates in col. (1), increase days of paid leave for mothers by 7 or by $16 \%$ of the mean.

Firms with a larger fraction of their workforce in childbearing age offer more leave. The coefficients are largest for the fraction in the GenX (born 1965 to 1979) and Millennial (born 1980 to 2000) groups, that is those who were 17 to 37 years old in 2017.35 The omitted group is mainly the Baby Boom generation, born 1946 to 1964 .

Interestingly, the results are similar for men's PPL benefits (col. 2). As mentioned before, men receive fewer weeks than do birth mothers because of the implicit (or explicit) short-term disability portion of PPL. The relationship to state laws is a bit more tenuous and that may be because men take less leave than do women and the issue of "topping off" is less important for them.

In sum, the analysis of the GPTW dataset shows that larger firms, those with

\footnotetext{
32 The median and mean given are for the Table 2, col. (1) firms. Firms with more than $90 \%$ female are mainly in Health and Professional services and they contain both small and large firms (e.g., Bright Horizons has many thousands of employees whereas Beyond Blue Consulting is small).

33 These estimates come from using the fact that the regression goes through the means.

34 The rationale is simply the law of large numbers.

35 The age cutoffs are from the Great Place to Work website from which we obtained these data.
} 
workforces disproportionately in the childbearing ages, and firms that have either a high or a low percentage of female employees offer the most leave. These findings are consistent with the implications of the model we developed to explain why firms offer PPL at all and why some offer more than others. ${ }^{36}$

The GPTW data are less clear about the degree to which workers accumulate firmspecific human capital, a critical part of the model and our understanding why firms provide PPL. The fact that PPL generosity is highest in the professional, technical, and finance sectors, is suggestive of that factor. ${ }^{37}$

b. Law, Accounting, and Finance: Expanding the Sample

We noted before that because the GPTW dataset contains firms that are the "better places to work", they have benefit programs almost by definition. To explore a less select group of firms, we expanded the sample in three sectors for which we could compile a full listing of the largest firms.

In the case of law firms, we have used the ALM Intelligence Legal Compass, which lists information on every law firm. In the case of accounting we have used the list in Accounting Today and for finance we used a host of lists, since the industry is broad and encompasses several different sectors from banking to insurance. ${ }^{38}$

Our next challenge was to find the relevant information on benefits for the firms on these lists. Armed with a fairly complete listing of firms, we then did an intensive search for benefit programs using company websites, other on-line information and direct contact. These methods provided us with a reasonably good sense when a PPL benefit exists and when it does not. We have listed, in Table 3, the distribution of weeks of PPL (for mothers), including the zeros, for the three industry groups.

In the law and finance groups about $20 \%$ of the firms have no benefits, whereas about a half of the accountancy firms have none. Law has significant bunching at both 60

\footnotetext{
${ }^{36}$ As we noted previously, we do not have a good sense which firms offer no PPL (or PFL). In doing a deeper dive into three professional service sectors, we uncovered a number of firms that have no PPL or PFL. Our analysis suggests that these firms are smaller than the median firm in their industry. But otherwise we cannot identify any obvious differences between them and other firms of their size. These firms may soon converge on the PPL and PFL benefits of their closest competitors in the labor market as has occurred among the larger firms in various industries. 37 Data from the 2004 SIPP indicate that the prevalence of on-the-job training (OJT) is positively related to firm size, wages, employee educational attainment, and being in a service-providing (versus goods-producing) sector. The prevalence of 0JT is particularly high in finance, real estate, and insurance (Small Business Administration 2009).

${ }^{38}$ For more details, see Appendix: Firm Level Data (Expanded GPTW Dataset).
} 
and 90 days, which is not surprising given that competition for lawyers is regional, if not national. Finance is less bunched probably because the job categories are broad. Accountancy has the largest variance in size. Although there is little bunching overall in PPL levels, there is some for the four largest national accounting firms.

In all three industries, firms without PPL are those with lower than average employment levels although the relationship is not always very strong. Some of the correlation could be because it is harder to obtain reliable data on small firms. But the smallest of our accountancy firms have around 250 employees and the smallest in the finance group have around 500 employees. ${ }^{39}$ We do not think that we are missing a publicly stated leave policy because a firm is small, but we are surely missing leaves that are negotiated separately by individual employees.

By using the ALM Intelligence Legal Compass we were able to find detailed information on the employee makeup of law firms including the fraction at different ranks and the fraction female at each rank. We have included, in Table 2, two columns on the lawyers (cols. 3 and 4) that report the correlates in a manner that is similar to those for the larger sample (cols. 1 and 2) drawn from the GPTW dataset.

The most important correlate for the lawyers is the fraction of the employees who are associates. These would be the youngest workers and would be the ones the firms would be trying to attract and keep to determine if they should eventually make partner. The fraction who are equity partners has a slight negative impact. The other categories are non-equity partner and an "other" category of lawyers that is a non-ladder group. The fraction of the group that is female does not matter much. The main factor in analyzing the law firm data is the fraction in the associate pool. Given the sample size and the bunching at various levels, we do not think that adding more variables is sensible.

\section{c. Relationship between State and Firm PPL and PFL Policies}

Some firms in our sample have headquarters in states that have long had a PFL policy, such as CA. But some are in states that have only recently passed PFL or passed a law just after our cutoff year (around 2017). State policies could have been anticipated, although there have been PFL policies floating around many state legislatures for some time. Another potential issue is that the location of the home office of a firm may not be the location of the majority of its employees. It would be very difficult to obtain estimates of

\footnotetext{
${ }^{39}$ We mean that in the finance group we encounter somewhat more zeros around 500 employees but the very smallest of the firms is around 200 employees. Finance also contains mega-firms with more than $200 \mathrm{~K}$ employees.
} 
the number of employees in each state.

The question is whether firms in states with active or anticipated PFL laws by 2017 have more or less generous paid family leave policies. On average, the states with PFL policies have firms with more generous PPL benefits (see Table 2 cols. 1 and 2). The causal channel could be that if a firm is on the margin of instituting PFL and PPL benefits, the implicit subsidy from the state, due to the ability to "top-off" the payment to the worker by the state, will push them over the edge. ${ }^{40}$

Much of the previous literature on PFL and PPL has examined state policies and some of that research has analyzed the relationship between state and firm policies. Appelbaum and Milkman (2011) surveyed firms in CA and found that although workers registered slim awareness of the state program, employers stood ready to provide this information when needed. According to the authors, employers with their own PPL receive an implicit subsidy from the state program and, since these firms tend to employ higher wage workers, their programs are used to "top-off" the state amount.

Bana, Bedard, Rossin-Slater, and Stearns (2018; see also Bana, Bedard, and RossinSlater 2018), examine the role of employer characteristics in the take-up of DI and PFL in CA and find, consistent with Appelbaum and Milkman (2011), that employees in larger and higher-wage firms have greater take-up of both. Again, a major reason is that employers with the most generous policies encourage workers to use the state system to reduce the firm's contribution when they "top-off" the state payout.

State fixed effects have been added for the states (and DC) that have policies or passed a relevant law around 2017.41 CA and NJ laws went into effect in 2004 and 2009 respectively. NY enacted a law in 2016 that became effective in 2018. WA enacted one in 2017 that took effect in 2019. The DC and MA laws were passed in 2017 and 2018 respectively and are not yet operational at the time of this writing. Eligible MA employees can apply for benefits in 2021 and those in DC can apply in 2020. CT and OR passed laws that will just begin collecting taxes in January 2022.

Relative to states with no PFL laws, the aggregated PFL states have firms with more generous paid leave (Table 2, cols. 1 and 2, given industry, size of firm, and the included employee characteristics). But the results are mixed at the individual state level. CA and WA firms offer more generous paid leave benefits, but NJ firms do not. NY firms are more

\footnotetext{
40 There is another reason for the relationship. States may allow firms to have their own policies and avoid the tax, as a form of self-insurance. The state of Washington has such a policy termed a "voluntary plan." See https://esd.wa.gov/paid-family-medical-leave/voluntary

41 There are no firms in the data set with a home office in Rhode Island.
} 
generous than those in the average state, but MA, with the most recently passed law, is not. The results for the law firms (Table 2, cols. 3 and 4) do not indicate any clear relationship between the state law of the firm's headquarters and the firm's PPL. ${ }^{42}$ Our results are correlational but cannot be considered causal given our single cross section of data.

\section{E. Fully Paid Personal Time Off (PTO) Days}

Thus far, we have analyzed the provision of fully paid leave to new mothers and fathers for a birth or adoption. ${ }^{43}$ Firms also provide paid leave for other reasons. Almost all firms provide paid sick and vacation leave to their full-time employees. Some firms designate paid leave that can be taken for a host of reasons including caregiving to family members. These are generally called "discretionary leave" or "paid time off" (PTO) days. Many firms aggregate vacation, sick leave, and discretionary leave into one bundle of PTO days that can be taken whenever the employees would like and can often be banked.

Days of "paid time off" are given in Table 4 by the six industry groups used previously, plus the industries that are not in those six categories. The variance in the number of PTO days is small and is far less than for parental leave, given in Table 1 . The lower variance is because most firms have paid vacation and sick days and provide, in total, about four to six weeks of PTO leave. The ordering of the industries is approximately the same as for maternity leave, but there is only a slight relationship between PTO days and maternity leave days.

\section{F. Discussion and Conclusions}

This paper has concerned the provision of paid family leave (PFL) and paid parental leave (PPL) by firms in states that currently have, and do not have, a paid leave policy.

The first point is that PPL and PFL provided by private-sector firms have been increasing. Using a cross-tabulated version of the BLS Employment Benefit Survey (EBS) data, we find that PFL increased from 2010 to 2018 across US firms from 11\% to 17\% of the total employment in firms. We have emphasized that the EBS measure includes all employment in firms that offer some PFL even if all employees are not covered. The EBS data do not divulge the precise fraction of workers in these firms covered by the policies and the rate of coverage. We also find, using data compiled from Working Mother magazine,

\footnotetext{
42 Similarly, studies for the second half of the 1990s do not find a clear cross-country relation between firm-based extra-statutory maternity leave and the generosity of paid maternity leave provision (Evans, 2002; OECD, 2001). However, nations with extremely generous paid maternity leave (e.g., Sweden, Denmark, and Finland) had an extremely low number of workers reporting additional firm coverage.

${ }^{43}$ When a firm distinguishes between birth and adoptive parents, we record data for birth parents.
} 
that PPL increased considerably during the last 15 years for large firms in the professional service sector. For example, days offered increased in consulting from around seven weeks in 2003 to 15 weeks in 2017 for the median firm.

The next point concerns the length of leave. The individual level data from the NSFG show that among employees who could take paid leave, the mean leave taken is about eight weeks independent of education level. But the fraction of more-educated women who are able to take paid leave is considerably greater than for the less-educated. Even for the more-educated, about 20\% did not take any leave (and may have left the workforce at the time of the birth) and $65 \%$ of new mothers took advantage of paid leave. For the lesseducated group, $36 \%$ took no leave and just $36 \%$ of new mothers could access paid leave (the equivalence of those numbers is coincidental). Across all new mothers, $42 \%$ accessed some paid leave. The NSFG does not show increased leave during the 2000s decade, but it seems likely, given the evidence we have presented, that paid leave increased in the next decade.

Our firm-level data reveal large differences in paid leave by sector, size of firm, and fraction female. It appears that firms headquartered states with current paid leave laws have higher firm-based paid leave levels, which would be consistent with their topping off the amount given by the state. Although our firms are a special group that are more open about their leave policies, mean leave levels are not that much above those of workers in the NSFG.

The question we pose is why firms provide PPL and which firms do. To understand the provision of PPL we needed a larger group of identifiable firms that provide fully paid parental leave for all full-time workers. To accomplish this, we collected our own sample beginning with data from the aggregator Great Place to Work. The information we have compiled contains data on PPL and other benefits for 1,135 firms across a wide range of industries. We added data on employment, composition of the labor force, and geographic location of the headquarters.

We have been guided in our thinking by a simple two-period model in which male and female workers are identical except that female workers have a higher expected valuation of time outside the labor market after taking parental leave. Workers engage in training in the first period and reap its rewards in the second period. All workers have some probability of having a child between period 1 and period 2 . Because women have a higher value of home time, they will engage in less training and will be found in firms that hire workers with lower human capital. Firms offer PPL when a sufficient number of workers will return to the labor force in period 2. The model has implications for the provision of PPL. 
Our firm-level data show that firms that provide PPL are disproportionately those that hire workers who invest in firm specific human capital generally prior to the birth. The firms with more generous leave are larger. Their workforces are younger (but not too young). Our model, and the empirical results, do not tell us what relationship should exist between PPL and the fraction female. On the one hand, women have greater demand for PPL. But, on the other, they stand a higher probability of leaving the firm once they take it. One of our estimations prefers the quadratic form. Firms headquartered in states that already have PFL, tend to have more generous PPL policies.

But PPL across the firms in our sample is not very generous relative to that provided by many social insurance programs in other countries. The mean firm in our analysis sample (Table 2, col. 1, unweighted) gives 46 days to new moms. Firms in the top quarter offer at least 60 days or 12 weeks.

Our analysis sample contains only firms that offer positive amounts PPL. To learn more about the firms that do not offer PPL, we collected information from sectors for which we knew the identities of all firms above some size (e.g., accounting, finance, law). The conditional means in those samples are higher than in the analysis sample for all sectors. For example, the female lawyers in the median firm that offers some leave are offered 90 days or 16 weeks, and $18.5 \%$ of the firms offer no leave.

The vast majority of firms-88\% - that offer PPL to their female employees also offer PPL to their males employees. The average difference in leave length is 29 days (about five weeks) or approximately the short-term disability leave allotted to women when they have a birth. Firms realize that female employees would like the PPL benefit, but that if firms do not get sufficient buy-in from male workers, they would not be able to afford it. Therefore, many firms have been trying to encourage men to take PPL. ${ }^{4}$ This strategy may seem counter-productive. But it is not. If males and females both value PPL, then they are both willing to pay for it in terms of lower earnings. Firms will then be able to hire more women and be less constrained.

The business case for offering PPL is that workers value it sufficiently to pay for it when specific human capital bonds most workers to firms after the leave. A positive feature

\footnotetext{
${ }^{44}$ See Wall Street Journal article, "Want Equality: Make New Dads Stay Home" (Sept. 28, 2018), about a Boston-based company that offers fully-paid parental leave to its male and female employees who are new parents but also requires that all (male and female) employees take the leave. "As the co-founder of the company [Ben Waber, Humanyze co-founder] stated: "Bias plays such a clear role, we decided we are going to say, 'It's not an option. You [men] have to take the time off.' " As the author of the article noted: "After all, if men and women have to take equal leaves, there's no excuse to penalize either one." See Johnsen, Ku, and Salvanes (2019) for an estimate of the penalty men sustain who take daddy leave in Sweden.
} 
of firm-provided PPL is that firms benefit from getting buy-in from their male workforce. A critical negative feature is that lower-income members of the workforce will not be offered the benefit since they will be insufficiently bonded to the firm. There is a clear role for policy. State-mandated PFL or PPL fills a gap since more firms hiring low income workers will not provide it.

The landscape of PPL is changing rapidly for US firms. As more states are mandating PFL, firms that would have provided PPL (or PFL) in the absence of state requirements can top-off the amount given by the state. Male buy-in for state mandates has been meager because the replacement rate is low and negative future promotion effects may be high. A potential role exists for firms to top-off state-provided PPL and incentivize their male workers to support the higher levels of PPL that the firm would like to supply. 


\section{References}

Applebaum, Eileen, and Ruth Milkman. 2011. "Leaves That Pay: Employer and Worker Experiences with Paid Family Leave in California." Washington, D.C.: Center for Economic and Policy Research.

Bana, Sarah, Kelly Bedard, and Maya Rossin-Slater. 2018. "Trends and Disparities in Leave Use under California's Paid Family Leave Program: New Evidence from Administrative Data," American Economic Review Papers \& Proceedings (108): 388-91.

Bana, Sarah, Kelly Bedard, Maya Rossin-Slater, and Jenna Stearns. 2018. "Unequal Use of Social Insurance Benefits: The Role of Employers.” Working Paper (October 6).

Baum, Charles L., and Christopher J. Ruhm. 2016. "The Effects of Paid Family Leave in California on Labor Market Outcomes," Journal of Policy Analysis and Management 35(2): 333-56.

Brown, Charles, and James Medoff. 1989. "The Employer Size Wage Effect," Journal of Political Economy, 97(5): 1027-59.

Byker, Tanya. 2016. "Paid Parental Leave Laws in the United States: Does Short-Duration Leave Affect Women's Labor-Force Attachment?" American Economic Review Papers \& Proceedings 106(5): 242-46.

Dale-Olsen, Harald. 2006. "Wages, Fringe Benefits and Worker Turnover," Labour Economics, 13(1): 87-105

Davis, Steven J., and John Haltiwanger. 1996. "Employer Size and the Wage Structure in U.S. Manufacturing," Annales d' Economie et de Statistique, (January/July): 323-68.

Eriksson, Tor, and Nicolai Kristensen. 2014. "Wages or Fringes? Some Evidence on TradeOffs and Sorting," Journal of Labor Economics, 32(4): 899-928.

Evans, John M. 2002. “Work/Family Reconciliation, Gender Wage Equity and Occupational Segregation: The Role of Firms and Public Policy," Canadian Public Policy, 28: S187S216.

Fishback, Price V., and Shawn E. Kantor. 2000. A Prelude to the Welfare States: The Origins of Workers' Compensation. Chicago: University of Chicago Press. 
Johnsen, Julian, Hyejin Ku, and Kjell Salvanes. 2019. “Competition, Paternity Leave and Career Advancement." Paper presented at the NBER Summer Institute.

Kerr, Sari Pekkala. 2016. "Parental Leave Legislation and Women's Work: A Story of Unequal Opportunities," Journal of Policy Analysis and Management 35(1): 117-44.

Lazear, Edward P., and Sherwin Rosen. 1990. "Male-Female Wage Differentials in Job Ladders," Journal of Labor Economics, 8(1): S106-S123.

Manchester, Colleen F., Lisa M. Leslie, Tae-Youn Park. 2008. "Screening for Commitment: The Effect of Maternity Leave Usage on Wages.” Working Paper.

OECD (2001), "Balancing Work and Family Life: Helping Parents into Paid Employment," Chapter 5 in OECD Employment Outlook 2001: June, OECD Publishing, Paris.

Oyer, Paul. 2008. "Salary or Benefits," Research in Labor Economics, 28: 429-67.

Rossin-Slater, Maya, Christopher J. Ruhm, and Jane Waldfogel. 2013. "The Effects of California's Paid Family Leave Program on Mothers' Leave-Taking and Subsequent Labor Market Outcomes," Journal of Policy Analysis and Management 32(2): 224-45.

Small Business Administration. (2009). The Small Business Economy. A Report to the President. Washington, DC: US GPO.

Thomas, Mallika. 2019. "The Impact of Mandated Maternity Benefits on the Gender Differential in Promotions: Examining the Role of Adverse Selection." Cornell ILR working paper. March 6.

U.S. Department of Labor, BLS. 2017. National Compensation Survey: Employee Benefits in the United States (March), Bulletin 2787. https://www.bls.gov/ncs/ebs/benefits/2017/ebbl0061.pdf 
Figure 1: Fraction of Workers in Firms with Paid Family Leave by Industry

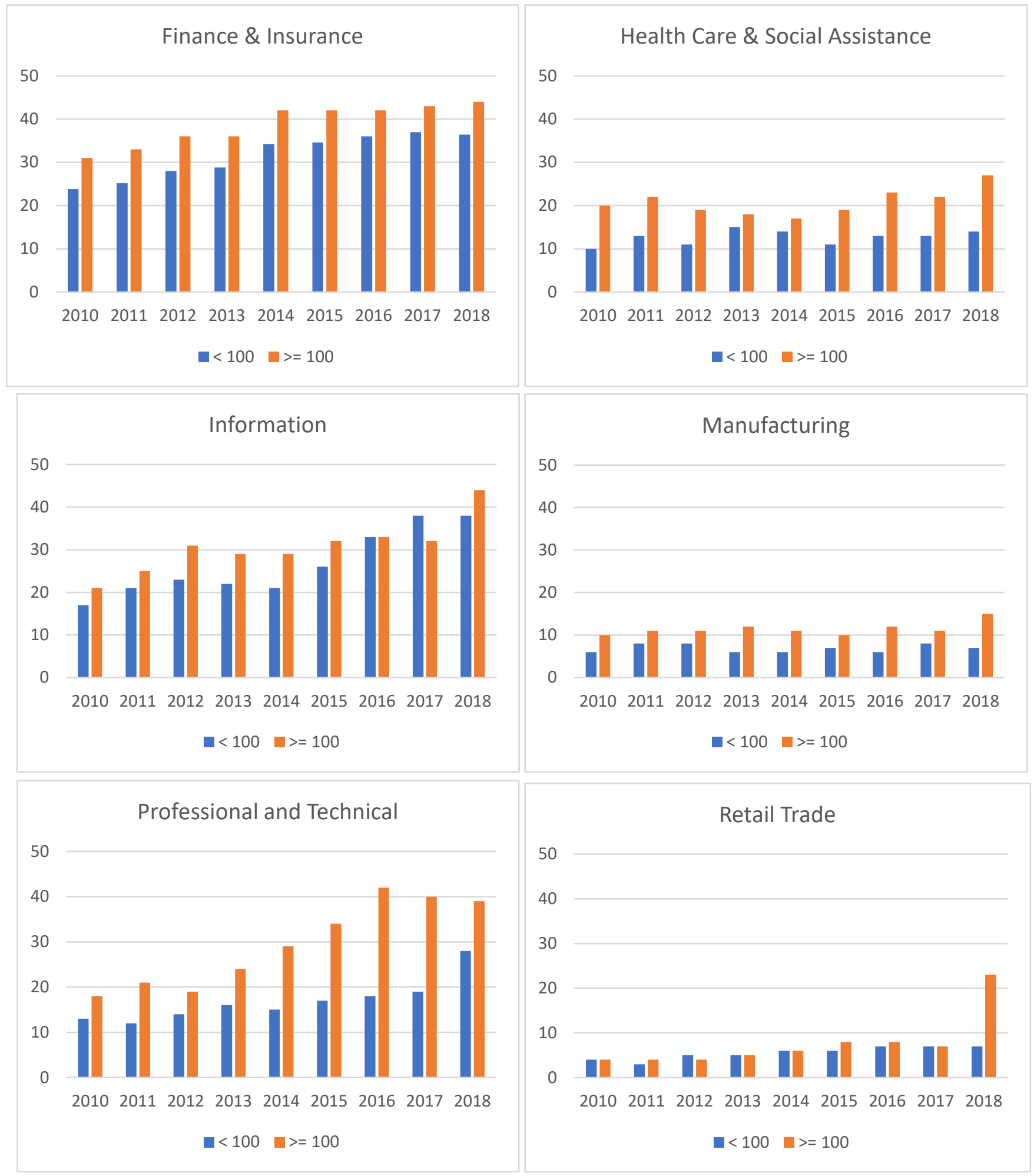


(Figure 1, continued)

Sources: BLS National Compensation Survey-Employee Benefits Survey (EBS).

https://www.bls.gov/ncs/ebs/home.htm The cross tabulations of industry by firm size were done by researchers at the BLS at the Office of Compensation and Working Conditions.

Notes: The EBS surveys firms about aspects of their benefit provision. The data are confidential and information about firm benefits is released in tabular form by industry, occupation, firm size, wage quantile, region, part-time status, and union status. BLS researchers created cross-tabulations for us of industry by firm size. The $<100$ and $\geq 100$ worker division provided the most cells that BLS could release. There are no small firms for colleges and universities. The spike for Retail Trade in 2018 is almost certainly due to Walmart's provision of paid family leave. 
Figure 2: Firm-Level Paid Parental Leave (PPL) and Paid Family Leave (PFL): c. 2017

A. Firm-Level Sample: Distribution of PPL by Weeks for Mothers

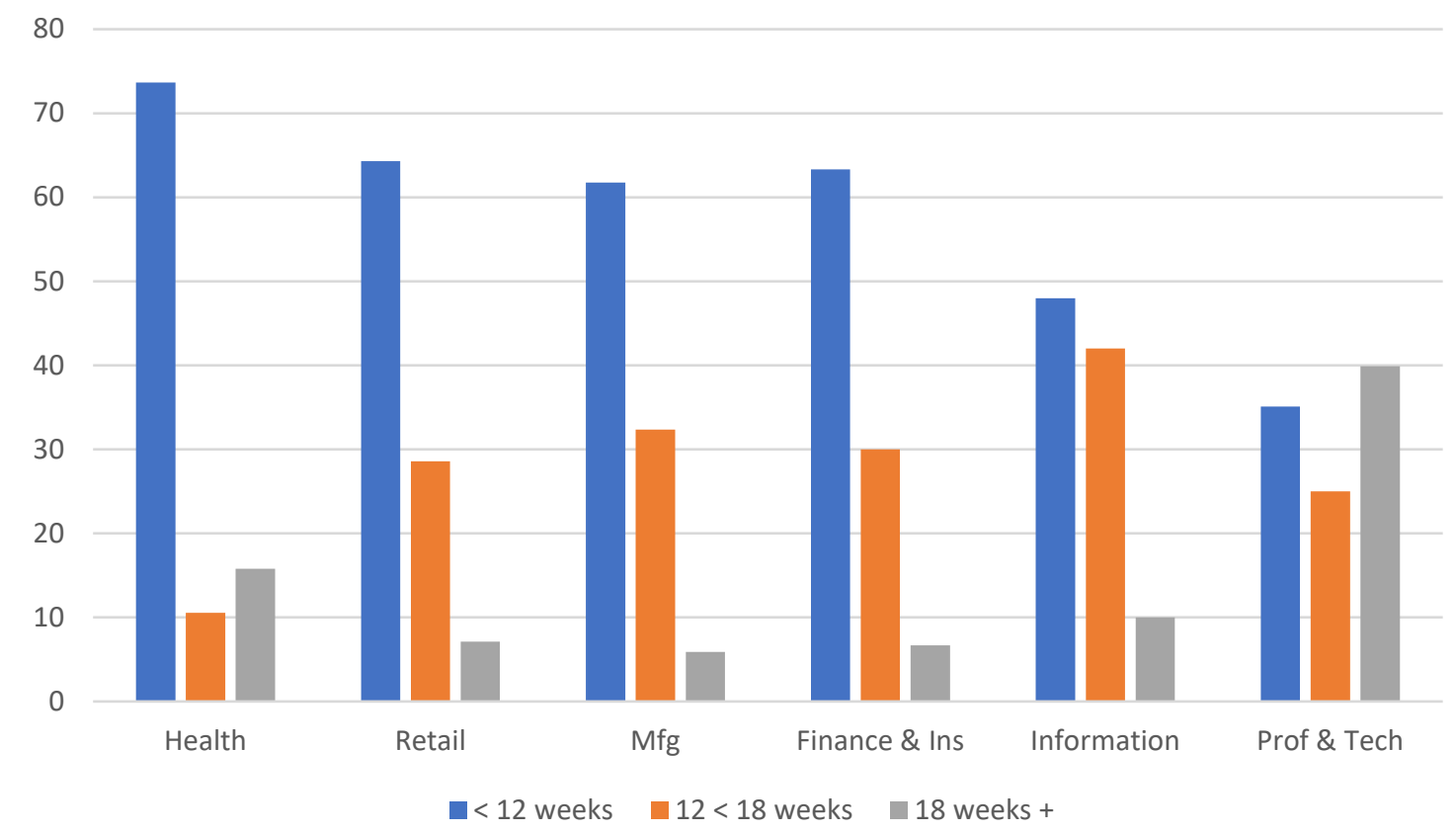

B. Fraction with Any Paid Family Leave: EBS for 2017

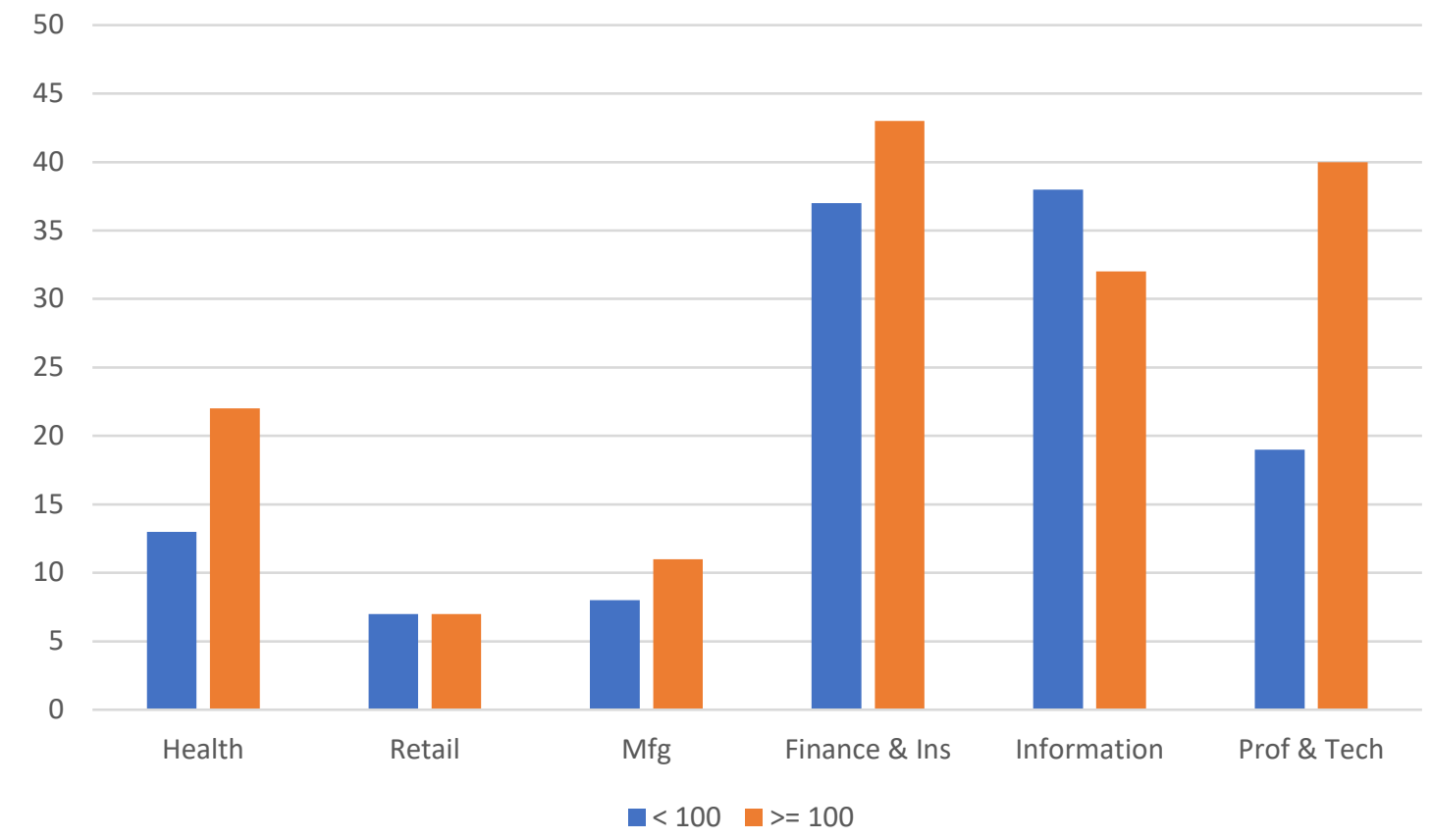


(Figure 2, continued)

Sources: Expanded GPTW Dataset. See Appendix: Firm-Level Data. See text for EBS sample.

Notes: The firms in part A are in the seven BLS industrial sectors that harmonize with those in the EBS. There are 686 firms across the seven sectors and 808 in the full sample with information on paid parental leave for mothers. We use 2017 in the EBS for consistency with our information for the separate firms. Note that all firms in Part A have some paid parental leave for mothers. 
Table 1: Summary Statistics on Paid Parental Leave (PPL) in Days for Mothers and Fathers by Industry, c. 2017

A. Analysis Sample, from Table 2, cols. (1) and (2)

\begin{tabular}{|c|c|c|c|c|c|c|}
\hline \multirow[b]{3}{*}{ Industry } & (1) & (2) & (3) & $(4)$ & (5) & (6) \\
\hline & \multicolumn{3}{|c|}{ Days PPL, Mothers } & \multicolumn{3}{|c|}{ Days PPL, Fathers } \\
\hline & Raw & Wted & (\# Firms) & Raw & Wted & (\# Firms) \\
\hline Health Care \& Social Assist. & 32.9 & 34.9 & (19) & 9.1 & 7.5 & (12) \\
\hline Retail & 49.6 & 50.4 & (14) & 19.5 & 29.3 & (11) \\
\hline Manufacturing & 47.0 & 56.3 & (33) & 22.3 & 28.6 & (28) \\
\hline Finance \& Insurance & 42.3 & 62.5 & $(60)$ & 23.8 & 34.1 & $(48)$ \\
\hline Information & 52.9 & 62.0 & (47) & 30.2 & 38.9 & (47) \\
\hline Professional \& Technical & 47.6 & 66.6 & (133) & 25.0 & 35.4 & (128) \\
\hline Industry not categorized & 41.9 & 25.2 & (78) & 19.1 & 14.7 & (62) \\
\hline Sample means & 45.6 & 53.9 & & 23.5 & 30.1 & \\
\hline Total number of firms & & & (384) & & & $(336)$ \\
\hline
\end{tabular}

B. Expanded GPTW Dataset

\begin{tabular}{|c|c|c|c|c|c|c|}
\hline & $(1)$ & (2) & (3) & $(4)$ & (5) & (6) \\
\hline & \multicolumn{3}{|c|}{ Days PPL, Mothers } & \multicolumn{3}{|c|}{ Days PPL, Fathers } \\
\hline Industry & Raw & Wted & (\# Firms) & Raw & Wted & (\# Firms) \\
\hline Health Care \& Social Assist. & 34.3 & 36.5 & $(20)$ & 13.0 & 12.7 & (13) \\
\hline Retail & 51.6 & 52.6 & $(48)$ & 28.8 & 26.1 & $(28)$ \\
\hline Manufacturing & 51.4 & 53.9 & (59) & 23.2 & 27.8 & $(50)$ \\
\hline Finance \& Insurance & 48.7 & 62.6 & $(123)$ & 24.9 & 33.8 & $(96)$ \\
\hline Information & 58.2 & 77.5 & $(70)$ & 32.4 & 40.7 & $(68)$ \\
\hline Professional \& Technical & 61.6 & 83.7 & $(320)$ & 29.1 & 46.4 & $(278)$ \\
\hline Industry not categorized & 47.6 & 45.5 & $(107)$ & 23.7 & 33.3 & $(82)$ \\
\hline Sample means & 55.0 & 68.6 & & 27.3 & 38.9 & \\
\hline Total number of firms & & & (747) & & & (615) \\
\hline
\end{tabular}

Source: Expanded GPTW Dataset. See Appendix: Firm-Level Data.

Notes: The sample in Part A is primarily the GPTW data and includes firms with information on fraction female and the age distribution of employees. These are the firms in the Table 2, cols. (1) and (2) regressions. The sample in Part B is the Expanded GPTW Dataset and includes only firms with positive levels of PPL and non-missing firm size (number of employees). We give the "raw" numbers, which are unweighted, and those that weight by the number of employees for comparability with the EBS estimates. The EBS data implicitly weight. 
Table 2: Correlates of Private-Sector Firm Paid Parental Leave (PPL): c. 2017

\begin{tabular}{|c|c|c|c|c|c|}
\hline \multirow{3}{*}{$\begin{array}{l}\text { Variables } \\
\end{array}$} & (1) & (2) & \multirow[b]{3}{*}{ Variables } & (3) & (4) \\
\hline & \multicolumn{2}{|c|}{ Sample with PPL $>0$} & & \multicolumn{2}{|c|}{ Sample with PPL $\geq 0$} \\
\hline & $\begin{array}{l}\text { PPL in Days } \\
\text { for Mothers }\end{array}$ & $\begin{array}{l}\text { PPL in Days } \\
\text { for Fathers }\end{array}$ & & $\begin{array}{l}\text { Lawyers, } \\
\text { Days for } \\
\text { Mothers }\end{array}$ & $\begin{array}{l}\text { Lawyers, Days } \\
\text { for Fathers }\end{array}$ \\
\hline $\begin{array}{l}\text { Mean of dept } \\
\text { variable: }\end{array}$ & 45.6 & 23.5 & $\begin{array}{l}\text { Mean of dept } \\
\text { variable: }\end{array}$ & 66.4 & 25.0 \\
\hline \multirow[t]{2}{*}{$\%$ Female } & $-0.755^{*}$ & $-0.786^{*}$ & & & \\
\hline & $(-1.98)$ & $(-2.44)$ & & & \\
\hline \multirow[t]{2}{*}{$\%$ Female $^{2}$} & 0.00709 & $0.00984^{* *}$ & & & \\
\hline & $(1.90)$ & $(3.09)$ & & & \\
\hline \multirow[t]{2}{*}{ Ln(Employ.) } & $1.586^{*}$ & $2.035^{* *}$ & \# Lawyers & 0.00619 & $0.00648^{*}$ \\
\hline & (2.11) & $(3.03)$ & & (1.43) & $(2.04)$ \\
\hline \multirow[t]{2}{*}{$\%$ Millennials } & $0.370^{*}$ & $0.357^{*}$ & \% Total Assoc. & $0.910^{* * *}$ & $0.477^{* *}$ \\
\hline & (2.39) & $(2.53)$ & & $(4.31)$ & $(3.09)$ \\
\hline \multirow[t]{2}{*}{ \% Gen X'ers } & 0.359 & $0.413^{*}$ & \% Tot Equity Part. & -0.519 & 0.111 \\
\hline & $(1.60)$ & $(2.00)$ & & $(-1.71)$ & $(0.50)$ \\
\hline \multirow[t]{2}{*}{$\mathrm{CA}$} & $13.54^{* *}$ & $9.511^{* *}$ & $\mathrm{CA}$ & 5.908 & -2.410 \\
\hline & $(3.29)$ & $(2.71)$ & & $(0.66)$ & $(-0.37)$ \\
\hline \multirow[t]{2}{*}{ DC } & -1.406 & 3.731 & DC & $25.64^{*}$ & 6.509 \\
\hline & $(-0.10)$ & $(0.34)$ & & $(2.50)$ & $(0.87)$ \\
\hline \multirow[t]{2}{*}{ MA } & 0.734 & 2.034 & MA & 10.60 & 0.0595 \\
\hline & $(0.08)$ & $(0.27)$ & & $(0.89)$ & $(0.01)$ \\
\hline \multirow[t]{2}{*}{$\mathrm{NJ}$} & -9.205 & 8.085 & NJ & -19.45 & 14.91 \\
\hline & $(-0.94)$ & $(1.01)$ & & $(-0.86)$ & $(0.90)$ \\
\hline \multirow[t]{2}{*}{ NY } & $9.786^{*}$ & $9.619^{*}$ & NY & 3.005 & -3.005 \\
\hline & (2.19) & (2.51) & & $(0.39)$ & $(-0.53)$ \\
\hline \multirow[t]{2}{*}{ WA } & 12.85 & 9.931 & WA & -8.131 & -11.26 \\
\hline & $(1.34)$ & $(1.32)$ & & $(-0.36)$ & $(-0.69)$ \\
\hline Industry f.e. & 2-digit SIC & 2-digit SIC & & & \\
\hline \multirow[t]{2}{*}{ Constant } & 18.79 & -12.64 & Constant & $30.09^{*}$ & -3.803 \\
\hline & $(0.98)$ & $(-0.73)$ & & $(2.19)$ & $(-0.38)$ \\
\hline $\mathrm{R}^{2}$ (adjusted) & 0.125 & 0.0981 & $\mathrm{R}^{2}$ (adjusted) & 0.277 & 0.0839 \\
\hline $\begin{array}{l}\text { Number of } \\
\text { observations }\end{array}$ & 384 & 336 & $\begin{array}{l}\text { Number of } \\
\text { observations }\end{array}$ & 147 & 147 \\
\hline
\end{tabular}

${ }^{*} \mathrm{p}<0.05^{* *} \mathrm{p}<0.01{ }^{* * *} \mathrm{p}<0.001$ 
Sources: Expanded GPTW Dataset. See Appendix: Firm-Level Data.

Notes: Employment is the number of US employees for the firm with the stated policy. Some firms may be subsidiaries of others but have different benefits. t-statistics are in parentheses.

Cols. (1) and (2): Firm employment data are from Dun \& Bradstreet. Post Millennials are birth years post-2000s; Millennials are 1980-2000; Gen X'ers are 1965-79. Omitted generation is those born before 1965, mainly Baby Boomers (1946-1964). Post-millennials are not listed since they are a small group and the coefficients are small and insignificant. Only firms with positive benefits are included. Industry fixed effects at the two-digit SIC level are included. Our results are fairly robust to using the four-digit SIC codes and the more aggregated NAICS codes.

Cols. (3) and (4): The ALM Intelligence Legal database is the main source that provides information on the number of lawyers per firm as well as their distribution by sex and level (e.g., equity partners, associates). Firms with no PPL are included. Approximately $18 \%$ of the law firms in this sample offer no PPL to mothers, which is approximately the same as in the total sample of law firms (see Table 3). In addition, $28.5 \%$ offer no PPL to fathers. 
Table 3: Distribution of PPL (for Mothers) in Three Sectors: c. 2017

\begin{tabular}{|l|c|c|c|c|c|c|}
\hline \hline \multirow{2}{*}{$\begin{array}{l}\text { Days of PPL } \\
\text { for Mothers }\end{array}$} & $\begin{array}{c}|c| \\
\text { Number of } \\
\text { Firms }\end{array}$ & \% of Firms & $\begin{array}{c}\text { Number of } \\
\text { Firms }\end{array}$ & \% of Firms & $\begin{array}{c}\text { Number of } \\
\text { Firms }\end{array}$ & \% of Firms \\
\hline No PPL & 32 & 18.5 & 49 & 50.5 & 35 & 21.7 \\
\hline 1 to 20 & 5 & 2.9 & 16 & 16.5 & 28 & 17.4 \\
\hline 21 to 30 & 1 & 0.6 & 4 & 4.1 & 19 & 11.8 \\
\hline 31 to 40 & 4 & 2.3 & 12 & 12.4 & 13 & 8.1 \\
\hline 41 to 50 & 2 & 1.2 & 4 & 4.1 & 7 & 4.4 \\
\hline 51 to 60 & 25 & 14.5 & 3 & 3.1 & 20 & 12.4 \\
\hline 61 to 70 & 1 & 0.6 & 3 & 3.1 & 9 & 5.6 \\
\hline 71 to 80 & 9 & 5.2 & 2 & 2.1 & 18 & 11.2 \\
\hline 81 to 90 & 77 & 44.5 & 3 & 3.1 & 6 & 3.7 \\
\hline 91 to 100 & 13 & 7.5 & 0 & 0 & 3 & 1.9 \\
\hline $101+$ & 4 & 2.3 & 1 & 1.0 & 3 & 1.9 \\
\hline Total & 173 & 100.0 & 97 & 100.0 & 161 & 100.0 \\
\hline \hline
\end{tabular}

Sources: Expanded GPTW Dataset. See Appendix: Firm-Level Data.

Notes: "No PPL" means that no information was found on websites and/or no information was provided during a call to a member of the HR team. It should be noted that this sample contains firms that are not in the regression sample in Table 2, cols. (1) and (2) because information on the other variables was not available. 
Table 4: Paid Time Off (PTO) Days by Industry: c. 2017

\begin{tabular}{|l|c|c|c|}
\hline \hline Industry & $(1)$ & $(2)$ & $(3)$ \\
\hline Health Care \& Social Assist. & 19.87 & 0.038 & 82 \\
\hline Retail & 20.35 & 0.115 & 26 \\
\hline Manufacturing & 24.35 & 0.085 & 47 \\
\hline Finance \& Insurance & 25.36 & 0.110 & 82 \\
\hline Information & 24.94 & 0.485 & 66 \\
\hline Professional \& Technical & 25.45 & 0.301 & 183 \\
\hline Industry not categorized & 21.80 & 0.052 & 135 \\
\hline Total & & & 621 \\
\hline \hline
\end{tabular}

Source: Expanded GPTW Dataset. See Appendix: Firm-Level Data.

Notes: All the firms in this table are from the GPTW list since only those had information on fully paid discretionary days off. Col. (1) gives the number of fully-paid PTO days listed by the firm excluding those listing "unlimited." When firms had a short-term disability policy with no stated number of weeks, we assumed the firm provided 35 days, or seven weeks, since that is the average for short-term disability taken for maternity leave. Some firms did not list a number but stated that they had a policy or that the number of days was "unlimited." Col. (2) gives the fraction of firms with "unlimited" PTO. Col. (3) gives the total number of firms in each industry listing a benefit of fully-paid PTO days off. 
Appendix: Firm-Level Data

\section{GPTW Dataset}

We use multiple sources of both publicly available and proprietary (or subscriptionbased) data to collect information on parental leave policies in private US firms. We briefly describe the process of collecting and verifying data for a sample of 1,135 private firms. See also Appendix Tables 1 and 2. The main industries covered include (using the NAICS classifications): health (care \& social assistance), retail, manufacturing, finance \& insurance, information, and professional \& technical. Firms that are not in these six industries are classified as "Industry not categorized."

Multiple websites and magazines report information on the "family friendliness" of workplaces. The website "Great Place to Work" (GPTW) partners with companies to document and certify their workplace practices and employee benefits, and maintains a large, detailed company-level "database" on these certified companies by sector and geographic area. ${ }^{45}$

We used the GPTW website to obtain: 1) Total days of job protected leave for new mothers and fathers, 2) Total days of partially- or fully-paid leave for new mothers and fathers, 3) Total days of paid leave for personal use ("Paid Time Off"), and 4) the demographic composition of the workforce such as percent female and the age distribution. ${ }^{46}$ To supplement and verify the information from GPTW, we collected similar data from other on-line sources, including the Working Mother Magazine's Best 100 Companies annual listings and other aggregator websites such as Glassdoor, Indeed, Fairy God Boss, Law Crossings, and the Paid Leave for the United States (PL+US) campaign. Our research assistants scoured the web for information and cold-called hundreds of firms.

When we identified conflicting data for a company, we gave priority to the information from the firm's website-benefits page. To maintain comparability across firms, we used the following guidelines.

First, we focused on explicitly-stated maternity and paternity leaves applicable to birth mothers and birth fathers respectively. Many firms, especially recently, provide paid

\footnotetext{
${ }^{45}$ Great Place to Work website is https://www.greatplacetowork.com/.

46 The dataset provides information on the proportion of workers who were born between 1925 and 1945 (Silent Generation), 1946 to 1964 (Baby Boomers), 1965 to 1979 (Gen X), 1980 to 2000 (Millennials), and post-2000 (Post-Millennials).
} 
parental leave that can be used by mothers and fathers alike. In such cases, we assign the same number of days off to both mothers and fathers.

Second, some firms offer leaves for "primary caregivers" and "secondary caregivers." In those cases, we apply primary caregiver leaves to birth mothers and secondary caregiver leaves to birth fathers. A sex discrimination case against JPMorgan Chase was recently settled in favor of the plaintiff, a father (argued as a class action case). This case may alter our interpretation of benefits going forward.

Third, we do not consider leaves or monetary benefits offered to adoptive parents in the current analysis, although many provide them. Fourth, many websites note that shortterm disability (STD) leave is available but do not provide further details. Because the usual amount of STD is 6 to 8 weeks (six for normal delivery and up to eight for delivery by CSection), and can be used to fund maternity leave, we added 35 days of leave for birth mothers in firms that provide the benefit.

Many firms will require their workers to exhaust other paid leaves, such as vacation and sick days, before taking parental leave. We do not include vacation or other paid days off (e.g. sick leave or personal days) in our estimate of maternity and paternity leave. We include those days under the "Paid Time Off" category. ${ }_{47}$

For each firm in our sample, we obtained data on its NAICS and SIC industry codes and employment from the Dun and Bradstreet company database, where available.

\section{Expanded GPTW Dataset}

Because the information we have collected comes from aggregators that are created to applaud the family-friendly policies of firms, we also sought to obtain fuller information for certain industries in which the top 100 to 200 firms by number of employees are clearly known. We have done that for three major professional fields: accounting, finance, and law.

To define the "universe" of top firms in these sectors we used the Accounting Todays' list of the 100 largest accounting firms in 2018, Internet Legal Research Group's America's Largest 150 Law Firms (as of 2015), and various lists of firms offering specific types of financial services (including US Federal Reserve's list of large commercial banks,

\footnotetext{
47 Some firms have replaced separate categories of leave such as vacation and sick days with an aggregate category called "Paid Time Off," which can be taken whenever employees need to and can often be banked. We cannot be certain whether the number of days for PTO in our dataset is inclusive or exclusive of other types of leaves.
} 
Broker-dealer firms based on assets under management, insurance firms, wealth management firms, and largest banks in the US by assets according to Wikipedia).

We searched for the parental leave policy for each of these firms by first visiting the benefits and career page on their websites and noting whether they mentioned having a parental leave program. If they did, we collected the details of the program. If the firm mentioned having a paid parental leave program without providing any additional details, we assumed a provision of 15 days, or 3 weeks, of paid time off for mothers (equal to the $25^{\text {th }}$ percentile of days available for mothers in our dataset). If a firm's website simply mentioned that it "Complies with FMLA," we coded the firm as having no paid days off for parental leave.

Once again, for each firm in our sample, we obtained data on its NAICS and SIC industry codes and employment from the Dun and Bradstreet company database, where available.

Additional details about data construction by sector are provided below. A summary of the number of firms in each of these areas is given in the following table:

\begin{tabular}{|l|c|c|c|c|c|}
\hline \hline & \multicolumn{5}{|c|}{ Number of Firms } \\
\cline { 2 - 6 } Industry & GPTW+ & $\begin{array}{c}\text { Expanded } \\
\text { Sample }\end{array}$ & $\begin{array}{c}\text { With Total } \\
\text { Employment }\end{array}$ & $\begin{array}{c}\text { With PPL } \\
\text { Information } \\
>0 ;>=0\end{array}$ & $\begin{array}{c}\text { With \% } \\
\text { Female }\end{array}$ \\
\hline Accountancy & 12 & 98 & 93 & $41 ; 98$ & 12 \\
\hline Finance \& Insurance & 88 & 162 & 159 & $119 ; 158$ & 81 \\
\hline Law & 9 & 177 & 151 & $145 ; 173$ & 140 \\
\hline \hline
\end{tabular}

Notes: GPTW+ is the original sample from GPTW and other sources. Expanded Sample is described below for each of the three industries but also includes the group in GPTW+. With Employment means that we have obtained reliable information on the number of employees. PPL is the existence of information on Paid Parental Leave for mothers; $>0$ means that these are the firms that listed positive PPL. With \% Female means that the firm had information on the fraction of its workforce that is female. In the case of Law Firms, the employees are all lawyers. The number of firms is given with information on each variable.

\section{a. Law Firms Dataset}

We have used the ALM Intelligence Legal database for information on the total number of lawyers in each firm, and the numbers in each of the various lawyer categories (associate, equity partner, non-equity partner, and other lawyer) by gender. We searched websites and called the law firms to ascertain their level of PPL benefits. We assigned a zero level to firms whose benefits we could not reasonably find and learn of in other ways. 
We began with the Internet Legal Research Group's America's Largest 350 Law Firms (as of 2015). We obtained ALM data on 177 firms of which 173 had sufficient information to determine their PPL policies and 147 had complete information on lawyers by staff level in the firm.

b. Accounting Firms Dataset

Similar to the law firm dataset, we began with a known list of firms and then searched websites and called firms to learn of their PPL policies. We began with Accounting Today's list of the 100 largest accounting firms in 2018, and we obtained information on employment for 97 of them ( 11 were already in the GPTW data). As, in the case of the law firms, if no information could be reasonably gathered on their PPL policies, we allocated the firm a zero.

c. Financial Firms Dataset

Financial firms can be of many types and have different functions. These include commercial banks, investment banks, insurance companies, brokerage firms and non-bank financial institutions such as credit unions. We assembled lists of each group and then searched for information on them. We assembled data in 163 firms and were able to assign PPL levels, including zeros, to 160 of them. 
Appendix Table 1: Availability of Data for Birth Mothers and Fathers

\begin{tabular}{|c|c|c|}
\hline Analysis Sample & Expanded GPTW Sample & Full Dataset \\
\hline $\begin{array}{l}\text { Data available on the following } \\
\text { variables: } \\
\text { - } \quad \text { Total days of partially or } \\
\text { fully paid days off for } \\
\text { mothers and fathers (only } \\
\text { firms with positive leave } \\
\text { are included) } \\
\text { - } \quad \text { Employment } \\
\text { - } \quad \text { Percent female } \\
\text { - } \text { Age (\% workforce in Silent } \\
\text { Generation (born between } \\
\text { 1925-1945), Baby Boomers } \\
\text { (1946-1964), Gen X (1965- } \\
\text { 1979), Millennials (1980- } \\
\text { 2000), and Post-Millennials } \\
\text { (2000 onwards) } \\
\text { State where the U.S. head } \\
\text { office is located }\end{array}$ & $\begin{array}{l}\text { Data found through Google } \\
\text { search to expand coverage of } \\
\text { firms in Law, Finance \& } \\
\text { Insurance, and Accounting } \\
\text { industries with available } \\
\text { information on: } \\
\text { - Total days of partially or } \\
\text { fully paid days off for } \\
\text { mothers and fathers }(>0) \\
\text { - Employment } \\
\text { - State where the US head } \\
\text { office is located }\end{array}$ & $\begin{array}{l}\text { Data available on at least one of } \\
\text { the following variables: } \\
\text { - Total job guaranteed days } \\
\text { off for mothers (1,131 non- } \\
\text { missing) } \\
\text { - Total days of partially or } \\
\text { fully paid days off for } \\
\text { mothers ( } 960 \text { non-missing) } \\
\text { - Total job guaranteed days } \\
\text { off for fathers ( } 968 \text { non- } \\
\text { missing) } \\
\text { Total days of partially or } \\
\text { fully paid days off for } \\
\text { fathers (710 non-missing) }\end{array}$ \\
\hline $\begin{array}{l}\text { Mothers: } 384 \text { firms } \\
\text { Fathers: } 336 \text { firms }\end{array}$ & $\begin{array}{l}\text { Mothers: } 747 \text { firms } \\
\text { Fathers: } 615 \text { firms }\end{array}$ & lotal: 1,13 \\
\hline
\end{tabular}


Appendix Table 2: Number of Firms in Sample for Birth Mothers (Fathers) by Industry

\begin{tabular}{lccc}
\hline Industry & Analysis Sample & $\begin{array}{c}\text { Expanded GPTW } \\
\text { Sample }\end{array}$ & Full Dataset \\
\hline Health Care \& Social Assist. & $19(12)$ & $20(13)$ & 90 \\
Retail & $14(11)$ & $48(28)$ & 75 \\
Manufacturing & $33(28)$ & $59(50)$ & 73 \\
Finance \& Insurance & $59(48)$ & $123(96)$ & 162 \\
Information & $47(47)$ & $70(68)$ & 81 \\
Professional \& Technical & $133(128)$ & $320(278)$ & 447 \\
Industry not categorized & $78(62)$ & $107(82)$ & 207 \\
\hline Total & $384(336)$ & $747(615)$ & 1,135 \\
\hline \hline
\end{tabular}


Appendix: Two-Period Model of Paid Parental Leave (PPL)

We consider a two-period model $\left(\mathrm{P}_{t}, t=1,2\right)$, where each period is normalized to one.

A continuum of firms $(i=1, \ldots, N)$ exists and each firm has a productivity factor, $\left(\phi_{i}\right)$, that determines the minimum level of firm-specific investment $\left(\alpha_{i}\right)$ required of a worker in firm $i$. Firms can operate with workers who exceed the minimum, but not with workers who have less.

In addition, a continuum of male and female workers, (M, F), exists on the unit interval each with a baseline productivity of $\omega$. Men and women sort into firms by their (firm-specific) investment levels. Investment is determined as follows.

In $\mathrm{P}_{1}$, each worker chooses whether to invest and, if so, the fraction of the first period to spend in firm-specific investment, denoted by $\alpha$. Workers who invest $\alpha$ are paid:

$$
w_{t}= \begin{cases}(1-\alpha) \omega & t=1 \\ \omega+(1+r) \alpha \omega & t=2\end{cases}
$$

where $r$ is the rate of return to human capital investment $\mathrm{P}_{1}$. The only pecuniary cost of the investment is foregone earnings in $\mathrm{P}_{1}$. Workers also face an investment effort cost, $\varepsilon$, which is known and identically distributed across genders according to the cumulative distribution function, $\Sigma$. Workers who do not invest receive a wage $w_{t}=\omega$ in both periods.

Each male and female worker has a newborn, between $\mathrm{P}_{1}$ and $\mathrm{P}_{2}$, with probability $p$, and each takes a fraction, $\lambda$, of $\mathrm{P}_{2}$ as fully-paid leave, if it is offered by the firm. All workers in firms without paid leave take a minimum amount of unpaid leave, denoted as $\underline{\lambda}$, if they have a birth.

At the end of the leave period, parents choose whether or not to return to work. They do so only if their $\mathrm{P}_{2}$ wage, $w_{2}(\alpha, r)$, over the remainder of the period, $(1-\lambda)$, exceeds the value of time with their child, $v$, which is a random variable revealed to the worker only after the birth.

The only difference between men and women is the distribution function of $v$. That for men, $G_{m}(v)$, is stochastically dominated by the distribution for women, $G_{f}(v)$. That is, $G_{m}(v) \geq$ $G_{f}(v) \forall v$, with strict equality over some interval. Women are, ex-ante, willing to pay more than are men for the paid family leave benefit because they have a higher value of nonmarket time (in expectation). Note, however, that a worker's investment choice occurs prior to knowing the value of time with their newborn, $v$.

Formally, a worker (M, F) with investment effort cost $\varepsilon$ chooses firm-specific investment, $\alpha$, in $\mathrm{P}_{1}$ to maximize: 


$$
\begin{aligned}
& E V\left(\alpha ; \lambda, p, r, w, G_{f, m}\right)=w_{1}(\alpha)+w_{2}(\alpha, r)-\varepsilon \alpha+ \\
& p(1-\lambda)\left(1-G_{f, m}\left(w_{2}(\alpha, r)\right)\right)\left(E\left(v \mid v \geq w_{2}(\alpha, r)\right)-w_{2}(\alpha, r)\right)
\end{aligned}
$$

The first line of the equation is the (net) return of $\mathrm{P}_{1}$ investment in the absence of $\mathrm{P}_{2}$ children. The second line is the (net) opportunity cost of the investment in $\mathrm{P}_{2}$. That value is the difference between the gained (conditional) expected utility and the foregone investment income (in expectation) if, at the end of the leave, the worker exits the firm. The higher the investment, $\alpha$, and the higher the rate of return, $r$, the more likely is the worker to return to the firm at the end of the leave period. This the PPL demand-side of the model.

The assumption that women have a higher expected value of nonmarket time ( $\left.G_{m} \geq G_{f}\right)$ implies that, all else being equal, a lower fraction of women will choose a positive investment. Moreover, at any $\alpha^{*}$ the fraction of women whose cost of effort is low enough, according to the distribution function $(\Sigma)$, is smaller than that of men, since they are less likely to return to the firm if they have a birth. Formally, define $\mathrm{F}\left(\alpha^{*}\right)=\Sigma\left(\varepsilon_{f}^{*}\right)$ and $\mathrm{M}\left(\alpha^{*}\right)=\Sigma\left(\varepsilon_{m}^{*}\right)$ as the shares, respectively, of women and men who invest $\alpha^{*}, \mathrm{~F}\left(\alpha^{*}\right)<\mathrm{M}\left(\alpha^{*}\right)$. The higher the $\alpha^{*}$, the lower the share of women who will be willing to invest. Ordering the $N$ firms by their required firmspecific investment and denoting by $\alpha_{\text {min }}$ the minimum required amount, we also have that (1 $\left.\mathrm{F}\left(\alpha_{\text {min }}\right)\right)>\left(1-\mathrm{M}\left(\alpha_{\min }\right)\right)$. That is, women are more likely to be found in no-investment firms (those with flat wage profiles). We assume that no-investment firms do not offer paid leave, but that all of their workers with a birth take $\underline{\lambda}$ without pay.

Since there is a continuum of firms ordered by the minimum $\alpha$ requirement, workers sort into them based on their investment decisions. We assume that employers are subject to antidiscrimination laws and hire men and women based only on their period one training. There is no separating equilibrium whereby women would like to enter a firm but are barred.

Profit maximizing firms effectively "offer” a wage profile over the two periods (which depends on $\alpha$ and $r$ ) and the benefit PPL $=\lambda$, to satisfy workers' incentive compatibility constraint (that is, the solution from the worker's problem above) subject to a free entry condition. We assume that all firms offer (or have) the same $r$ and that $\lambda$ is pinned down by the "zero profit” condition, which means that workers as a group pay for their leave. Formally:

$$
\begin{aligned}
&(1-p) w_{2}(\alpha, r)+p(1-\lambda) G_{f, m}\left(w_{2}(\alpha, r)\right) w_{2}(\alpha, r)+\omega- \\
& \frac{\lambda p}{(1-p)+p(1-\lambda)\left(1-G_{f, m}\left(w_{2}(\alpha)\right)\right)} w_{2}(\alpha, r)-(1-\alpha) \omega=0
\end{aligned}
$$


where the first line is expected gain to the firm over the two periods and the second line is expected cost. This is the PPL supply-side of the model.

The properties of the reduced form equilibrium condition of our model - the implicit function $\lambda(\alpha)$-depend on two different constraints. First, since workers as a group effectively pay for their leave, the more workers remain at the firm in $\mathrm{P}_{2}$, the less costly is the benefit to all workers. This mechanism implies that firms requiring higher $\alpha$ would offer higher $\lambda$. The second condition is the incentive compatibility constraint. The slope of $\lambda(\alpha)$ resulting from the worker's first-order condition will depend on the properties of the $G$ distribution function. Using a Pareto distribution, $G(v)=1-\left(\frac{1}{v}\right)^{\gamma}$ with $\gamma>1$ and $E(v)=\frac{\gamma}{\gamma-1}$, the first-order condition becomes:

$$
\frac{d E V}{d \alpha}=r \omega-\varepsilon+p(1-\lambda) \omega^{2}(1+r)^{2}\left(\frac{1}{\omega+\omega(1+r) \alpha}\right)^{\gamma-2}=0
$$

Define the above function as $\mathrm{Z}(\alpha, \lambda)$. Using the implicit function theorem, by total differentiation we can show that $\lambda(\alpha)=-\mathrm{Z}_{\alpha} / \mathrm{Z}_{\lambda} \geq 0$ for $1<\gamma \leq 2$ and $\lambda(\alpha)<0$ for $\gamma>2$.

In the first case, $(1<\gamma \leq 2), \lambda(\alpha)>0$ for any $\alpha$, as given in Appendix Figure 1a. The relationship between $\alpha$ and $\lambda$ is monotonic and $\lambda$ is strictly increasing in $\alpha$. This case occurs when the expected value of being home is relatively high. In the second case $(\gamma>2)$, the equilibrium curve could exhibit a U-shape, as given in Appendix Figure 1b. This case means that the $G$ distribution is more concentrated around low values of $v$. (The expected value is between 1 and 2.) Therefore, more employees will go back to their firm at the end of their leave.

Appendix Figure 1: PPL, Firm-Specific Investment $(\alpha>0)$ and Percent Female $(\pi)$

Panel a:

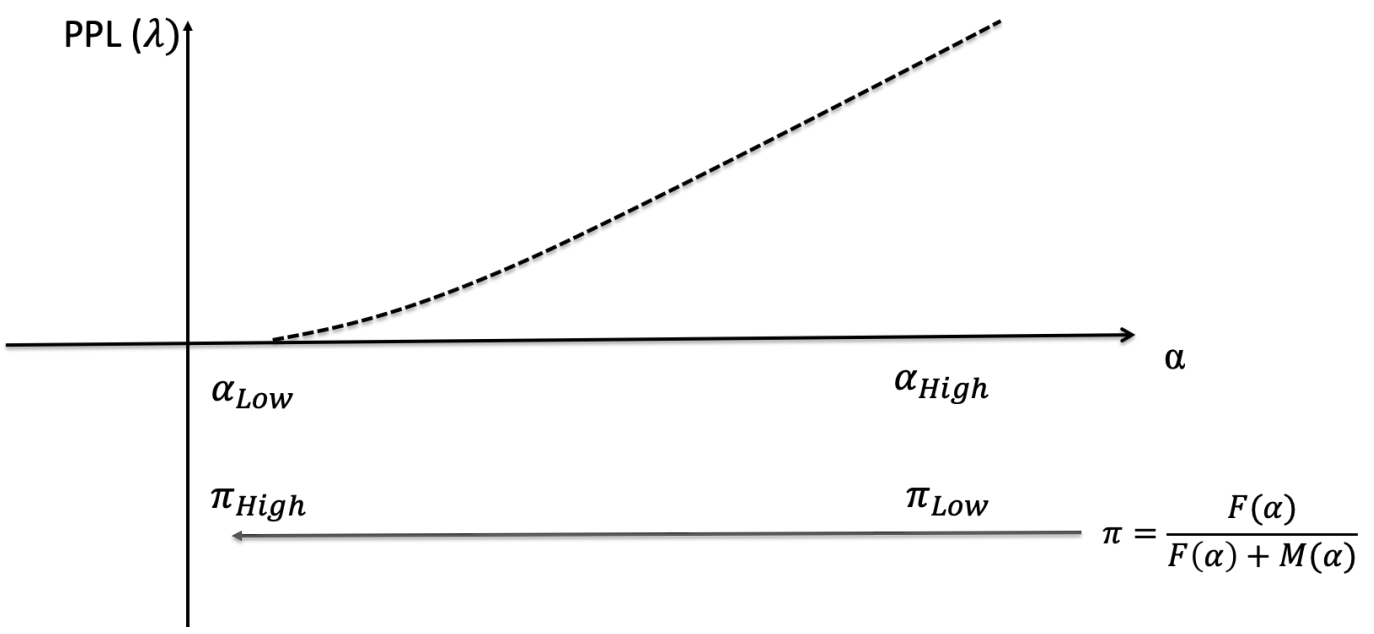


Panel b:

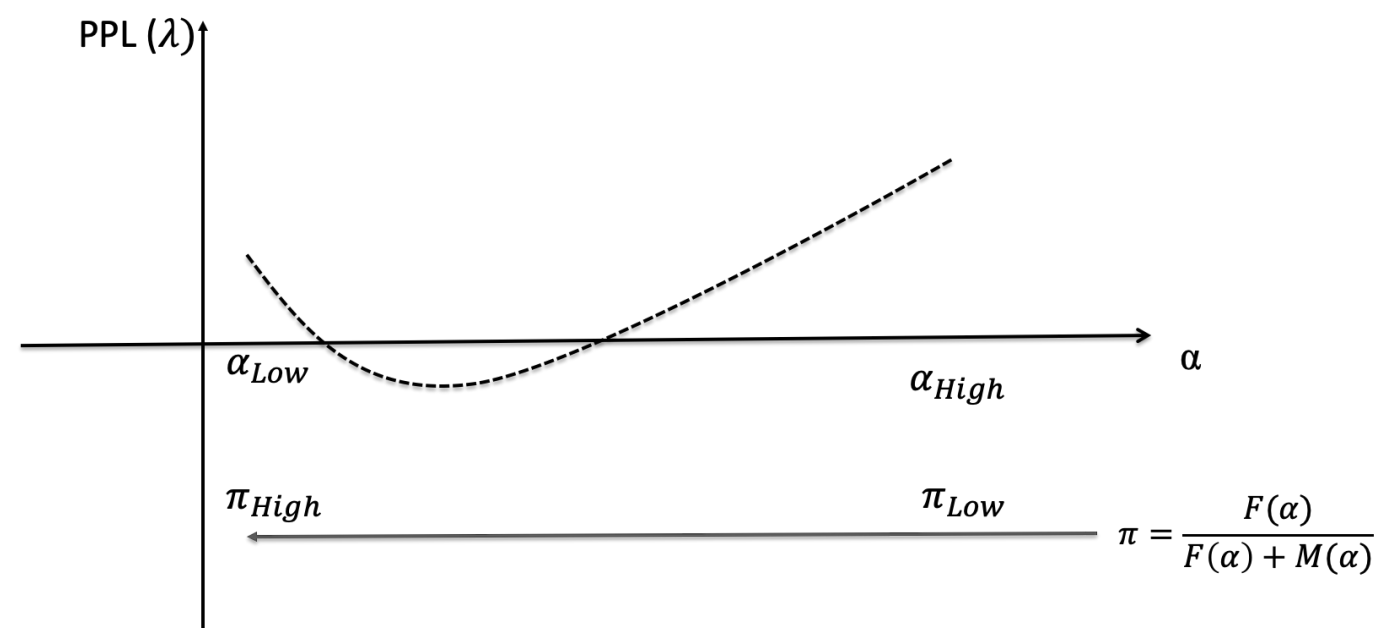

Version of: 12/31/19 42 